\title{
BDNF and NT-4/5 Prevent Atrophy of Rat Rubrospinal Neurons after Cervical Axotomy, Stimulate GAP-43 and T $\alpha 1$-Tubulin mRNA Expression, and Promote Axonal Regeneration
}

\author{
Nao R. Kobayashi, ${ }^{1,2}$ Da-Peng Fan, ${ }^{2}$ Klaus M. Giehl, ${ }^{1}$ Annie M. Bedard, ${ }^{1}$ Stanley J. Wiegand, ${ }^{3}$ and \\ Wolfram Tetzlaff ${ }^{1,2}$ \\ 1Department of Physiology, University of Ottawa, Ontario, Canada KIH 8M5, 2Departments of Zoology and Surgery, \\ University of British Columbia, Vancouver, British Columbia, Canada V6T 1Z4, and ${ }^{3}$ Regeneron Pharmaceuticals Inc., \\ Tarrytown, New York 10591-6707
}

\begin{abstract}
Rubrospinal neurons (RSNs) undergo a marked atrophy in the second week after cervical axotomy. This delayed atrophy is accompanied by a decline in the expression of regenerationassociated genes such as GAP-43 and T $\alpha 1$-tubulin, which are initially elevated after injury. These responses may reflect a deficiency in the trophic support of axotomized RSNs. To test this hypothesis, we first analyzed the expression of mRNAs encoding the trk family of neurotrophin receptors. In situ hybridization revealed expression of full-length trkB receptors in virtually all RSNs, which declined $7 \mathrm{~d}$ after axotomy. Full-length trkC mRNA was expressed at low levels. Using RT-PCR, we found that mRNAs encoding trkC isoforms with kinase domain inserts were present at levels comparable to that for the unmodified receptor. TrkA mRNA expression was not detected in RSNs, and the expression of p75 was restricted to a small subpopulation of axotomized cells. In agreement with the pattern of trk receptor expression, infusion of recombinant human
\end{abstract}

BDNF or NT-4/5 into the vicinity of the axotomized RSNs, between days 7 and 14 after axotomy, fully prevented their atrophy. This effect was still evident 2 weeks after the termination of BDNF treatment. Moreover, BDNF or NT-4/5 treatment stimulated the expression of GAP-43 and T $\alpha 1$-tubulin mRNA and maintained the level of trkB expression. Vehicle, NGF, or NT-3 treatment had no significant effect on cell size or GAP-43 and $\mathrm{T} \alpha 1$-tubulin expression. In a separate experiment, infusion of BDNF also was found to increase the number of axotomized RSNs that regenerated into a peripheral nerve graft. Thus, in BDNF-treated animals, the prevention of neuronal atrophy and the stimulation GAP-43 and T $\alpha 1$-tubulin expression is correlated with an increased regenerative capacity of axotomized RSNs.

Key words: axotomy; spinal cord injury; neurotrophin; regeneration, red nucleus; gene expression; neuronal atrophy; cell body response; peripheral nerve transplant
Within the CNS, axons usually fail to regenerate after injury, whereas successful axonal regeneration occurs in the peripheral nervous system (PNS) (Ramon y Cajal, 1928/1991). This failure has been attributed to the presence of inhibitory molecules in the mature CNS (Caroni and Schwab, 1988; Bovolenta et al., 1993; McKerracher et al., 1994; Mukhopadhyay et al., 1994; Schachner et al., 1994), and in addition to the death or atrophy of the parent cell body (Barron et al., 1989; Aguayo et al., 1991; Giehl and Tetzlaff, 1996) and to intrinsic factors (Barron et al., 1989; Chen et al., 1995), such as the failure of the injured CNS neurons to express regeneration-associated genes (Skene, 1989; Tetzlaff et al., 1991, 1994). For example, we have shown that after axotomy

\footnotetext{
Received April 24, 1997; revised Sept. 17, 1997; accepted Sept. 25, 1997.

This study was supported by an operating grant from the Medical Research Council of Canada and the Neuroscience Network of Canada to W.T. N.R.K. is a recipient of the Government of Canada Studentship Award, supplemented by the Neuroscience Network of Canada. K.M.G. was supported by a Canadian Neuroscience Network fellowship. W.T. is a recipient of the Rick Hansen Man in Motion Chair in Spinal Cord Research. BDNF, NT-3, NT-4/5, and the NT-4/5 antibody were kindly provided by Regeneron Pharmaceuticals Inc. (Tarrytown, NY). We thank Dr. Eugene Johnson (University of Washington, St. Louis, MO) for providing the NGF antibody and Dr. James Miller (Amgen, Thousand Oaks, CA) for providing NGF and the antibodies to BDNF and NT-3.

Correspondence should be addressed to Dr. Wolfram Tetzlaff, Department of Zoology, University of British Columbia, 6270 University Boulevard, Vancouver, British Columbia, Canada V6T 1 Z4.

Dr. Giehl's present address: Department of Anatomy, University of Saarland, D66421 Homburg, Germany.

Copyright (C) 1997 Society for Neuroscience $\quad 0270-6474 / 97 / 179583-13 \$ 05.00 / 0$
}

at the cervical level of the spinal cord, GAP-43 and T $\alpha 1$-tubulin expression are increased transiently in rubrospinal neurons (RSNs) (Tetzlaff et al., 1991). This observation correlates with the growth of a small percentage (1-2\%) of RSN axons into the permissive environment of peripheral nerves implanted into the cord at the level of transection (Richardson et al., 1984; Houle, 1991; Tetzlaff et al., 1994). However, the very limited regeneration of RSN axons into the grafts may reflect an impaired regenerative propensity of these neurons, which is likely related to the severe atrophy that occurs during the second week after cervical axotomy (Egan et al., 1977; Barron et al., 1989; Tetzlaff et al., 1991). Concomitant with this massive neuronal atrophy, the number of axotomized RSNs that express GAP-43 and T $\alpha 1$-tubulin decreases markedly during the second week after injury (Tetzlaff et al., 1991). Here, we test the hypothesis that the atrophy and decline in regeneration-associated gene expression observed in axotomized RSNs are caused by a lack of trophic support, and that these effects may be prevented by the application of exogenous trophic factors. The trophic dependency of RSNs in adult rats is not well understood, and in this study we focused on the family of neurotrophins and their receptors.

The neurotrophin family of factors, comprising nerve growth factor (NGF), brain-derived neurotrophic factor (BDNF), neurotrophin-3 (NT-3), and neurotrophin-4/5 (NT-4/5), has been shown to influence neuronal survival and differentiation during development, as well as maintenance of neuronal phenotype and 
modulation of synaptic efficacy in the adult nervous system (for review, see Korsching, 1993; Davies, 1994; Lindholm et al., 1994; Lindsay et al., 1994; Bonhoeffer, 1996; Lewin and Barde, 1996). The trk family of receptor tyrosine kinases has been identified as the high-affinity, signal-transducing receptor for the neurotrophins (for review, see Kaplan and Stephens, 1994; Barbacid, 1995; Bothwell, 1995). Based largely on in vitro transfection studies in PC -12 cells and fibroblast cell lines, NGF is considered to be the primary ligand for TrkA, BDNF, and NT-4/5 for TrkB, and NT-3 for TrkC (Klein et al., 1991a,b, 1992; Lamballe et al., 1991; Soppet et al., 1991; Squinto et al., 1991; Ip et al., 1993). Insertions in the tyrosine kinase domain of the TrkC alter the signaling capacity of this receptor in response to NT-3 binding (Tsoulfas et al., 1993, 1996; Valenzuela et al., 1993; Guiton et al., 1995). Thus, the cellular responsiveness to NT-3 is likely influenced by the presence of the various receptor isoforms.

In the present study, we report that RSNs express mRNA for full-length trkB and low levels of noninserted and inserted trkC but no trkA receptors. Application of BDNF or NT-4/5, but not NGF or NT-3, fully prevented the atrophy of axotomized RSNs and also stimulated the expression of GAP-43 and T $\alpha 1$-tubulin. Infusion of BDNF also was found to increase the number of axotomized RSNs that regenerated into grafts of sciatic nerve implanted into the cervical cord at the level of spinal transection.

\section{MATERIALS AND METHODS}

Animals and surgery. Male Sprague Dawley rats (Charles River Laboratories, Wilmington, MA) $(220-250 \mathrm{gm} ; n=112)$ were used for this study. They were kept in a $12 \mathrm{hr}$ light/dark cycle and fed a standard rodent diet ad libitum. All experiments were performed in accordance with the guidelines of the Canadian Council for Animal Care and approved by the local animal care committee. All surgery was performed under anesthesia with sodium pentobarbital $(32 \mathrm{mg} / \mathrm{kg})$ plus chloral hydrate $(150 \mathrm{mg} / \mathrm{kg})$ in sterile conditions.

Spinal cord hemisection. The neck musculature was split in the midline, and left hemilaminectomy was performed at C3/C4. After the dura was opened, the dorsolateral funiculus of the spinal cord was cut with a pair of iris scissors, and the incision was verified with a fine Dumont no. 5 forceps. In some animals, a small piece of gelfoam (Upjohn, Kalamazoo, MI) soaked with $0.5-1.0 \mu \mathrm{l}$ of $2 \%$ FluoroGold (FG) (Fluorochrome Inc., Eaglewood, CA) was applied to the injury site. The muscles were sutured with prolene (6-0) (Ethicon, Somerville, NJ), and the skin was closed with wound clips. Rats used for the in situ hybridization (ISH) and RT-PCR study of neurotrophin receptor expression $(n=14)$ were killed by an overdose of chloral hydrate $7 \mathrm{~d}$ after axotomy, and the fresh midbrains were immediately frozen on dry ice. In all other experiments, rats were injected with an overdose of chloral hydrate and perfused transcardially with PBS followed by freshly hydrolyzed paraformaldehyde $(4 \%$ in $10 \mathrm{~mm}$ phosphate buffer.

Neurotrophin application. RSN atrophy and the expression of GAP-43 and $\mathrm{T} \alpha 1$-tubulin were assessed in animals that were treated with recombinant human (rh) NGF, rhBDNF, rhNT-3 or rhNT-4/5, or vehicle. On day 7 postaxotomy, rats were anesthetized, and cannulae $(28 \mathrm{ga}, 8 \mathrm{~mm}$; Plastic One Inc., Roanoke, VA) were inserted stereotaxically into the vicinity of the red nucleus at the following coordinates: anterior-posterior $6.3 \mathrm{~mm}$ posterior to Bregma, medial-lateral $-1.7 \mathrm{~mm}$ (to the right of midline), and dorsal-ventral $-6.5 \mathrm{~mm}$ (from the cortical surface). The cannulae were anchored in position with two watchmaker screws and dental cement. Osmotic minipumps (Alzet no. 2001) $(1 \mu \mathrm{l} / \mathrm{hr}$ ) were filled with either vehicle alone [20 mM sterile PBS supplemented with $100 \mathrm{U}$ penicillin/streptomycin and $0.5 \%$ rat serum albumin (no. A-6272; Sigma, St. Louis, MO)], rhNGF, rhBDNF, rhNT-3, or rhNT-4/5 at a concentration of $500 \mathrm{ng} / \mu \mathrm{l}$. Pumps were connected to the infusion cannulae with $6-8 \mathrm{~cm}$ of SILASTIC tubing (no. 508-003, VWR Canlab), and the entire assembly was preincubated for $4-12 \mathrm{hr}$ in sterile $20 \mathrm{~mm}$ PBS at $37^{\circ} \mathrm{C}$ before implantation. Thus, each treated animal received $12 \mu \mathrm{g}$ of rhNGF, rhBDNF, rhNT-3, or rhNT-4/5 per day in a total volume of $168 \mu \mathrm{l}$ over a period of $7 \mathrm{~d}$ (between day 7 and 14 postaxotomy).

Peripheral nerve implants. To evaluate the effect of BDNF treatment on the regenerative capacity of axotomized RSNs, segments of peripheral nerve were implanted into the hemisected spinal cord. The right sciatic nerve was transected at the level of the obturator tendon and left in situ to allow Wallerian degeneration of the distal stump. Ten days later, a $30-35 \mathrm{~mm}$ segment of the predegenerated nerve was resected, and its proximal end was inserted into a $\mathrm{C} 4$ left spinal cord hemisection site. It was held in place with two Prolene 10-0 sutures (Ethicon, Somerville, $\mathrm{NJ}$ ), and the distal free end was marked with a Prolene 6-0 suture (Ethicon) and left in the subcutaneous tissue. The spinal column from C3 to $\mathrm{C} 5$ was immobilized by placing three watchmaker screws into the right vertebral pedicles of $\mathrm{C} 3, \mathrm{C} 4$, and $\mathrm{C} 5$ and stabilized with bone cement (Ethicon, Peterborough, ON, Canada). During the same surgical session, an osmotic minipump was implanted as described above to administer BDNF into the vicinity of the RSNs. The rationale to apply BDNF for $7 \mathrm{~d}$ at the time of spinal cord injury and transplantation was based on the animal care regulation that recommends the number of surgical interventions (three instead of four operations). We documented a prolonged effect of BDNF beyond the period of application, which further justifies our design. Ten weeks after spinal cord injury, pump implantation, and transplantation, the rats were anesthetized again, and the free end of the nerve transplant was identified and mobilized. The distal end (1-3 mm) of the nerve graft was resected, and the freshly exposed end of the nerve was placed into a small polyethylene tubing filled with 5\% FG for $1 \mathrm{hr}$. Fourteen days later, the rats were overdosed with chloral hydrate and perfused with paraformaldehyde, as described above. After post-fixation overnight in the same fixative, the midbrains and cervical spinal cords were cryoprotected in $16 \%$ and $22 \%$ sucrose in $10 \mathrm{~mm}$ PBS and frozen in dry ice-cooled isopentane. The midbrains were cut in series at $14 \mu \mathrm{m}$ thickness. FG-labeled neuronal profiles were counted throughout the caudal $1 \mathrm{~mm}$ of the red nucleus. Care was taken to avoid double counting in adjacent sections. Student's $t$ test was used to compare the number of retrogradely filled, i.e., regenerating, neurons in BDNF-treated versus untreated rats.

$R T-P C R$. Fresh frozen midbrains from 10 rats at $7 \mathrm{~d}$ after spinal cord hemisection at the cervical level were used for RT-PCR analysis of trkB and trkC receptor expression. FG-filled axotomized RSNs were visualized with a fluorescent microscope and microdissected from 70- to $80-\mu \mathrm{m}$-thick serial sections through the caudal pole $(400 \mu \mathrm{m})$ of the red nucleus containing the magnocellular population. The contralateral red nuclei were identified and dissected under dark-field illumination. We determined in earlier experiments that retrograde-labeling of RSNs with FG had little effect on RNA expression (W. Tetzlaff, B. Tsui, A. M. Bedard, and S. Cassar, unpublished observation). Total RNA was extracted from red nuclei pooled from $2 \times$ five animals using Trizol (Life Technologies, Gaithersburg, MD) according to a standard protocol provided by the manufacturer, followed by DNase treatment. The procedures for RT-PCR and control experiments were essentially the same as in our previous study (Kobayashi et al., 1996). PCR for cyclophilin was included as a control, using the primers published in Mearow et al. (1993) to ensure that equivalent amounts of input cDNA were analyzed (data not shown). The trkB primers used have been described previously in Kobayashi et al. (1996). The trkC primers were previously used by Offenhauser et al. (1995) and designed to bracket the potential insertion site within the tyrosine kinase domain to reveal different trkC insertion isoforms. After 30 amplification cycles, trkC PCR products were run on a $5 \%$ polyacrylamide gel stained with ethidium bromide and visualized under UV light and photographed. For trkB serial dilution PCR, 25, 12.5, and $6.75 \mathrm{ng}$ of input cDNA were amplified for 25 PCR cycles, and trkB PCR products were run on $1 \%$ agarose gel, followed by Southern transfer to a nylon membrane (Zeta-probe, Bio-Rad, Hercules, CA). The membrane was subsequently hybridized with ${ }^{35}$ S-labeled trkB oligonucleotide probe internal to and not overlapping with the respective PCR primers according to the standard protocol (Sambrook et al., 1989). The PCR of input cDNA serial dilutions followed by Southern blotting were within the linear range as determined by phosphoimaging (Molecular Dynamics, Sunnyvale, CA) when 25 amplification cycles were used for trkB and 30 amplification cycles were used for trkC (noninserted trkC isoform at 299 bp; data not shown), respectively. These 50 mer were also used in our trkB and trkC in situ hybridization study (see ISH section) and had little homology to other trk receptors.

Immunocytochemical assessment of the neurotrophin distribution. Perfusion-fixed sections containing red nuclei were immunostained using antibodies for NGF, BDNF, NT-3, or NT-4/5. The specificity of the antibodies for their respective neurotrophin has been described previously (Anderson et al., 1995; Alderson et al., 1996). The concentrations of the primary antibodies were adjusted so that they exhibited equivalent 
levels of detection of the homologous neurotrophin on slot blots $(0.5-1.0$ $\mathrm{ng} / 8 \mathrm{~mm}^{2}$ ); 1:7500 for the turkey anti-BDNF antibody, 1:5000 for the turkey anti-NT-3 antibody, 1:15,000 for the goat anti-NGF antibody, and 1:10000 for the chicken anti-NT-4/5 antibody. No cross-reactivity with heterologous neurotrophins was apparent on slot blots or in perfusionfixed midbrain sections taken from animals that had been injected with 1 $\mu \mathrm{g}$ of the neurotrophins (data not shown). Primary antibody omission or preabsorption with the appropriate but not related neurotrophins also abolished specific immunostaining (data not shown). Primary antibodies bound to tissue were localized using an appropriate biotinylated secondary antibody (1:1500) and the avidin-biotin-peroxidase complex (Vectastain, Vector Laboratories, Burlingame, CA).

Histology and cell size measurements. Most neurotrophin-treated and vehicle-treated rats were killed on day 14 , except for six rats that were left beyond the cessation of neurotrophin application i.e., until day 21 or 28 . These rats were overdosed with chloral hydrate, followed by perfusion as described above. Frozen sections were cut coronally at $12 \mu \mathrm{m}$ through the midbrain and mounted onto Superfrost Plus slides (Fisher Scientific, Houston, TX). Each slide contained a section from two control animals that received no pump or a vehicle pump and from one or two animals treated with a neurotrophin. The order in which they were cut and positioned onto the slide was randomized. The midbrains were cut from caudal to cranial, and collection of sections was begun when 6-10 RSNs appeared at the caudal pole of the red nucleus and the following 35 sections were gathered. Sections 15,25 , and 35 were stained with $0.2 \%$ cresyl violet for cell profile measurement and photography. The remaining sections were stored at $-80^{\circ} \mathrm{C}$ for ISH analysis.

The cell profile sizes were measured using a computerized image analysis system. Two techniques involving computerized digitization of the cell image and profile measurement were used. In the first method, a $16 \times$ oil immersion objective (Zeiss) was used to crop the images, and the contour of each neuron containing a visible nucleus was traced. This contour was filled in, and the number of pixels was measured to obtain an arbitrary value for the cross-sectional cell area. In the second technique, a field comprising about half the red nucleus was digitally captured using a $10 \times$ objective. Subsequently the density threshold was determined to discriminate the stained neurons from the background. Only those cell profiles that were twice the size of an average glial cell were included in our analysis. Confluent neurons were separated with a digitized paintbrush. In both procedures, the operator was blinded to the treatment condition. Because both procedures yielded very similar results, the latter technique was used routinely. The size of neurons within the red nucleus is heterogeneous, and smaller neurons are located predominantly toward the cranial end of the nucleus; hence, axotomized neurons at the caudal pole of the red nucleus have a size similar to the uninjured neurons in the rostral portion of the magnocellular red nucleus. Thus, the average cell size of axotomized RSNs was normalized to that of its contralateral counterpart in sections 15,25 , and 35 , and values were expressed as a percentage of contralateral control for each level of the nucleus. These percentages from individual animals were subjected to statistical analysis (see Statistical Analysis), and the median percentage from the individual treatment groups plus the 25th-75th percentiles are presented. We also provided the actual cell profile size measurements at the level of section 25 obtained from perfusion-fixed midbrains of different animal groups (see Table 1).

$I S H$. The protocol given in Verge et al. (1992) was used with some modification. The trkA probe was complementary to bases 1198-1245 and was used previously by Verge et al. (1992). The full-length trkB probe was described in Kobayashi et al. (1996) and is complementary to bases 1363-1407 (Middlemas et al., 1991). The trkC probe (Giehl and Tetzlaff, 1996) was complementary to bases 2109-2272 (excluding 21342250), bridging the insertion site in the cytoplasmic tyrosine kinase domain (Valenzuela et al., 1993). The T $\alpha 1$-tubulin probe was a $50 \mathrm{mer}$ oligonucleotide complementary to the $3^{\prime}$-untranslated sequence of T $\alpha 1$ tubulin 5'-AAACCCATCAGTGAAGTGGACGGCTCGGGTCTCTGACAAATCATT CA-3', and the GAP-43 probe was complementary to bases 220-270 (Basi et al., 1987). For all probes, no similarities were found for other molecular sequences at a $75 \%$ cutoff level in a BLASTN database search at the National Center for Biotechnology Information (Altschul et al., 1990). These oligonucleotide probes were end-labeled with ${ }^{35}$ S-ATP using deoxynucleotide terminal transferase according to a standard protocol (Ausubel et al., 1987). For trk receptor ISH, sections collected from fresh frozen midbrains were hybridized to $10^{6} \mathrm{cpm}$ of the respective probe in $100 \mu \mathrm{l}$ of hybridization mixture for $16-18 \mathrm{hr}$ at $43^{\circ} \mathrm{C}$ [for details of the mixture, hybridization conditions, and washes, see
Verge et al. (1992)]. For GAP-43 and T $\alpha 1$-tubulin ISH, perfusion-fixed sections $(14 \mu \mathrm{m})$ were pretreated and hybridized to $10^{6} \mathrm{cpm}$ of probe for $16-18 \mathrm{hr}$ at $43^{\circ} \mathrm{C}$ [for details, see Giehl and Tetzlaff (1996)]. The slides were dipped in Kodak NTB-2 emulsion and were exposed for $2 \mathrm{~d}$ for T $\alpha 1$-tubulin, $7 \mathrm{~d}$ for GAP-43, 3 weeks for trkB, and 7-9 weeks for trkA and trkC. For trk receptor ISH, the sections were stained with $0.2 \%$ cresyl violet, dehydrated, and embedded in DePex (BDH Chemicals, Poole, UK). We confirmed that GAP-43 and T $\alpha 1$-tubulin probes gave a single band of expected size in Northern blots of RNA from facial nuclei under identical or less stringent hybridization conditions (Tetzlaff et al., 1991) Equivalent data were obtained for the oligonucleotide probes (data not shown). We performed RT-PCR for trkB and trkC, followed by Southern blotting. The trkB and trkC probes recognized the bands of expected size (see RT-PCR section). We obtained essentially the same results for GAP-43 and T $\alpha 1$-tubulin ISH in no-pump control animals and our previous study using cDNA probes of several hundred base pairs (Tetzlaff et al., 1991), except that the oligonucleotide probes in this study detected the low levels of GAP-43 and T $\alpha 1$-tubulin in the contralateral control RSNs because of their higher sensitivity.

Quantification of GAP-43 and Ta1-tubulin ISH signals. The Northern Exposure Image Analysis system (EMPIX, Mississauga, Ontario, Canada) equipped with a frame grabber for the integration of multiple frames was used, allowing us to capture pictures of the fluorescent FG-filled RSNs. This integration allowed us to visualize further the contours of the unstained contralateral neurons. RSNs (50-100) from each animal (two to four slides per animal) were analyzed for each probe. To obtain this number, we collected and analyzed three to five digitized images of the FG-filled RSNs from each section through the red nucleus. The fluorescent pictures of RSNs were loaded into one frame buffer, and corresponding dark-field images of the silver grains representing the ISH signal were captured into another frame buffer. The contours of the fluorescent-labeled cells were traced with a digitized mouse, and this contour was used as a mask in the other frame buffer, which contained the dark-field-illuminated silver grains. The area fraction occupied by the silver grains within this mask was measured and corrected for a background of the tissue. This corrected fraction was subsequently multiplied by the estimated volume of the neuronal cell body (assuming that the latter is spherical) to generate the "ISH signal/cell." The ISH signal/cell values of the axotomized RSNs were expressed as multiples of the mean ISH signal/cell of the contralateral RSNs. Only perfusion-fixed brain tissues were included in ISH quantification, because fixation was needed to retain FG-labeling after ISH procedures. Therefore, the numbers of animals for ISH quantification were smaller than those included in the cell size study.

Statistics. Because the cell size data as well as ISH quantification data were normalized and expressed as percentage of or multiples of contralateral values, we used Kruskal-Wallis one-way ANOVA on ranks to test the differences in median values among the different treatment groups. This test does not assume normal distribution or equal variance of data. To identify the groups that differ significantly from the control group (vehicle-treated group), Dunn's multiple comparison procedure was performed at the significance level of $p<0.05$. The actual cell profile sizes of the axotomized and contralateral RSNs within the same group were compared using paired $t$ test $(p<0.05)$. Groupwise comparisons of the contralateral RSNs as well as the axotomized RSNs among different groups were performed using Newman-Keuls test at the significance level of $p<0.05$.

\section{RESULTS}

\section{Neurotrophin receptor expression}

The expression of the trk family of neurotrophin receptors in RSNs $7 \mathrm{~d}$ after axotomy was studied by ISH to predict the possible responsiveness of RSNs to neurotrophins. TrkA ISH signal was not detectable in either unlesioned or axotomized RSNs (Fig. $1 a, b)$. However, interpeduncular neurons in the same sections as well as cholinergic basal forebrain neurons (Figueiredo et al., 1995) showed strong expression of trkA, ruling out technical problems (data not shown). In contrast, expression of full-length trkB mRNA was seen in virtually all uninjured RSNs, in agreement with the recent immunocytochemical study of Yan et al. (1997) (Fig. 1d). This expression was decreased to $0.7 \times$ the contralateral level $7 \mathrm{~d}$ after axotomy (Fig. 1c) and declined 
Axotomized
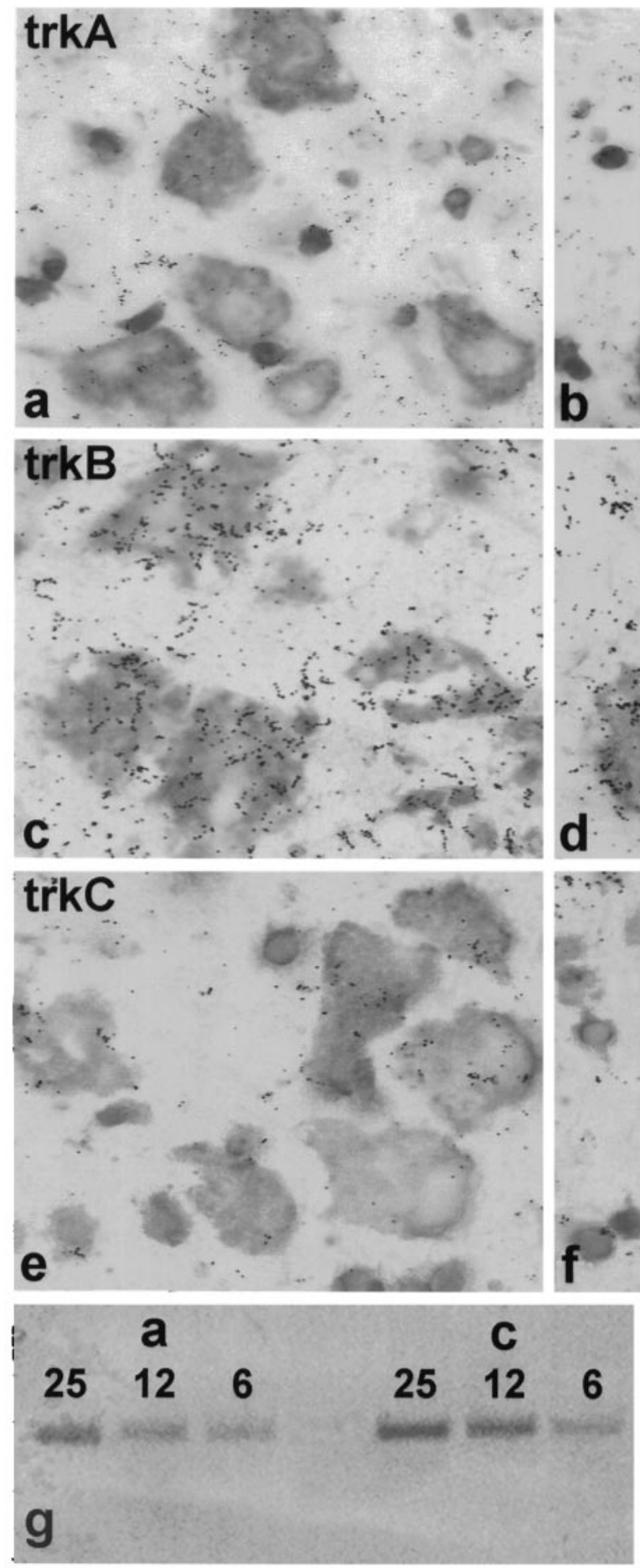

Contralateral
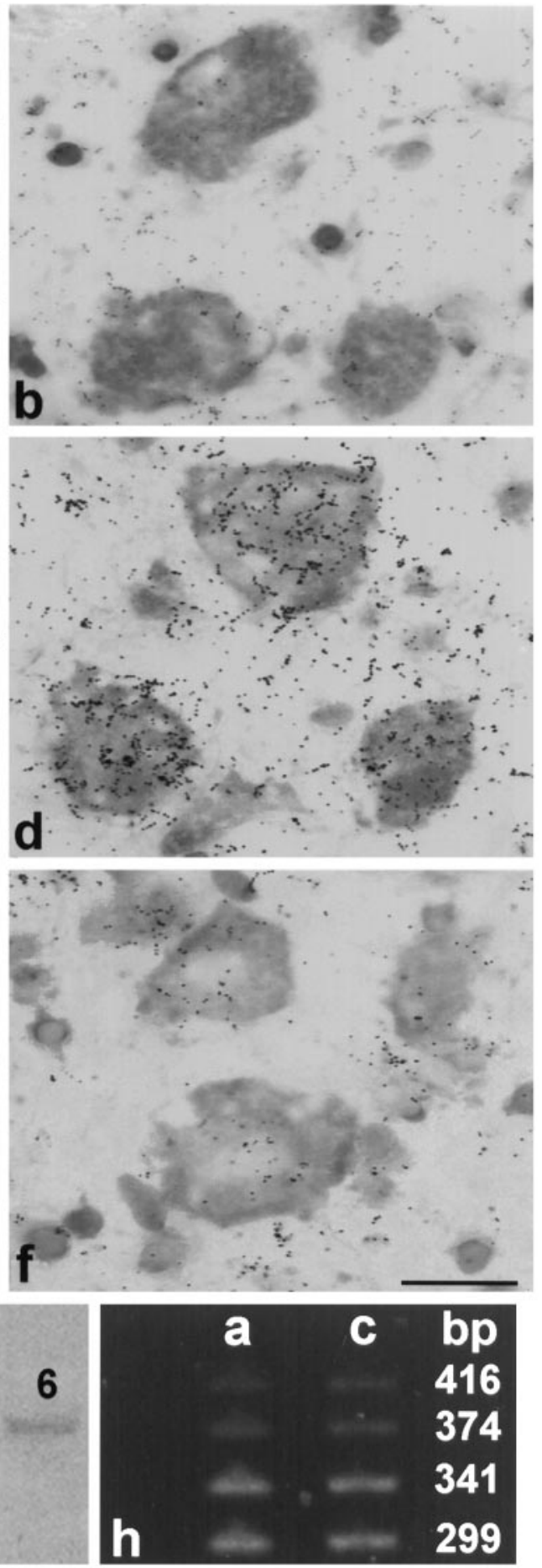

further thereafter as these neurons became atrophic during the second week after axotomy (data not shown). The expression of trkB in the red nucleus was confirmed by serial dilution RT-PCR (amplification of 25, 12.5, and 6.75 ng cDNA), followed by Southern blotting using a trkB probe internal to the PCR primers (Fig. $1 g$ ). This analysis also confirmed the ISH observation that the trkB expression was decreased in axotomized RSNs compared with the contralateral, intact RSNs (Fig. $1 g$ ).

TrkC isoforms having 14, 25, or 39 amino acids insertions in the kinase domain are commonly present in neural tissues (Tsoulfas et al., 1993; Valenzuela et al., 1993). Because these isoforms appear to be limited in their signaling capability (Guiton et al., 1995; Tsoulfas et al., 1996), we used an oligonucleotide probe bridging the insertion site to study the expression of the fulllength, noninserted trkC receptor. Weak expression of noninserted trkC mRNA was detected in uninjured and axotomized RSNs only after prolonged autoradiographic exposure (6-8 weeks) (Fig. 1f,e). Similar exposure times produced strong hy- 


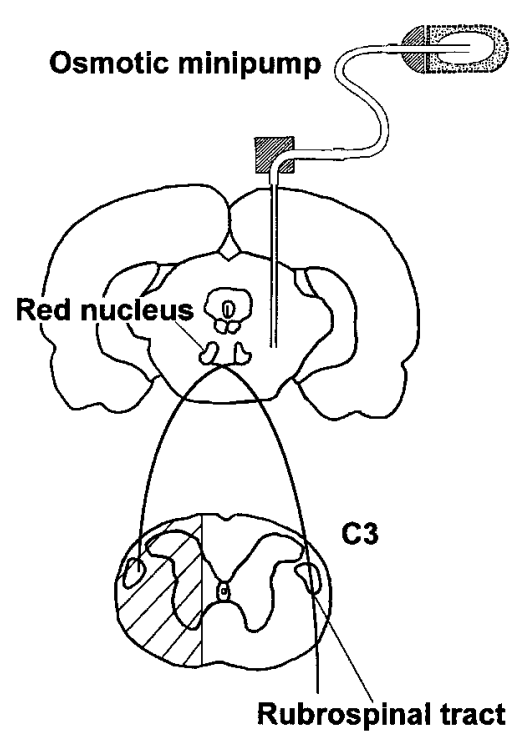

Figure 2. Schematic diagram showing the midbrain at the level of the red nucleus and the cervical spinal cord. The approximate insertion site of the application cannula connected to an osmotic minipump containing either vehicle alone or neurotrophins is illustrated in the coronal midbrain section. The hatched area in the spinal cord indicates the extent of transection at the cervical level $(C 3)$, which includes the rubrospinal tract.

bridization signals in corticospinal neurons (Giehl and Tetzlaff, 1996) and in facial motoneurons (K. L. Fernandes, N. R. Kobayashi, and W. Tetzlaff, unpublished observations). To further study the expression of trkC isoforms, we used trkC PCR primers bracketing the insertion site within the tyrosine kinase domain (Offenhauser et al., 1995). RT-PCR results revealed that both axotomized and contralateral RSNs expressed the noninserted (299 bp) as well as the known inserted isoforms (341, 374, and 416 bp) of the trkC receptor (Fig. $1 h$ ). The noninserted and 14 amino acid insert forms of trkC were the predominant types expressed in uninjured RSNs, and there was no apparent change in isoform composition $7 \mathrm{~d}$ after axotomy (Fig. $1 h$ ). The ISH analysis of the p75 neurotrophin receptor showed no signal in unlesioned RSNs. However, at $7 \mathrm{~d}$, but not 3 weeks postaxotomy, we found detectable p75 mRNA expression in the occasional axotomized RSNs $(<10 \%$; data not shown). Taken together, these observations suggest that axotomized RSNs may be responsive to BDNF and $\mathrm{NT}-4 / 5$, cognate ligands for the trkB receptor, and to NT-3, which preferentially binds to the trkC receptor.

\section{Distribution of infused neurotrophins}

The receptor expression profiles of RSNs provided the rationale for the application of the neurotrophins. These were infused between days 7 and 14 postaxotomy because acute axotomyinduced atrophy and concomitant decline in regenerationassociated gene expression occur in axotomized RSNs during this period (Tetzlaff et al., 1991). Figure 2 shows a diagram of an infusion cannula inserted into the vicinity of the red nucleus, which is connected to an osmotic minipump via SILASTIC tubing to apply $500 \mathrm{ng} \cdot \mu \mathrm{l}^{-1} \cdot \mathrm{hr}^{-1}$ of the appropriate neurotrophin. To assess the extent of factor distribution within the target tissue, midbrain sections were stained with antibodies to the various neurotrophins at the end of the $7 \mathrm{~d}$ infusion period. Immunostaining for rhNGF, rhNT-3, and rhNT-4/5 (Fig. 3a,c,d) revealed that these factors diffused over most of the midbrain tegmentum ipsilateral to the side of inf usion, filling a sphere of tissue $\sim 4 \mathrm{~mm}$ in diameter. In contrast, the diffusion of rhBDNF (Fig. 3b) was confined to an area within $1.0-1.5 \mathrm{~mm}$ of the cannula. These finding are consistent with the study of Anderson et al. (1995). Given the relatively limited diffusion of rhBDNF, for all of the factors we limited our analysis to those cases in which the cannulae were located within $0.5-1.0 \mathrm{~mm}$ of the lateral margin of the red nucleus. Cannula placements $<0.5 \mathrm{~mm}$ from the nucleus were excluded to rule out dendritic damage and nonspecific effects of trauma.

\section{Effects of neurotrophin infusion on RSN size}

Consistent with earlier findings (Egan et al., 1977), atrophy of RSNs was prominent $14 \mathrm{~d}$ postaxotomy. We found that the median of cell profile size of axotomized untreated RSNs decreased to $62.8 \%$ (25th-75th percentile: $59.6-66.6 \%$; $n=12$ ) of their uninjured contralateral counterparts. The infusion of BDNF or NT-4/5 completely prevented this axotomy-induced reduction in atrophy (Fig. $4 b$ vs $c, d$ vs $e$ ), whereas infusion of NGF, NT-3, or vehicle alone (Fig. $4 a$ vs $b$ ) did not affect the size of the axotomized RSNs. Interestingly, axotomized RSNs in BDNF- or NT-4/5-treated animals continued to exhibit classic signs of retrograde reaction to axotomy, including chromatolysis and a pronounced eccentricity of the nucleus. ANOVA on ranks (Kruskal-Wallis test) revealed significant differences $(p<$ $0.0001)$ in the median cell profile size expressed as percentage of contralateral between the treatment groups. The median percentage of the BDNF- $(105.2 \%$; 25th-75th percentile: $92.3-129.1 \%$; $n=9)$ and NT-4/5-treated $(107.0 \% ; 25$ th-75th percentile: $96.8-$ $111.3 \% ; n=7)$ groups was significantly different $(p<0.05$; Dunn's test) from the median percentage of the vehicle-treated group $(68.8 \%$; 25 th-75th percentile: $62.4-75.3 \%$; $n=15)$. Neither infusion of NGF $(72.1 \%$; 25th-75th percentile: $67.6-75.5 \%$; $n=6)$ nor of NT-3 $(84.6 \%$; 25th-75th percentile: $65.6-90.3 \%$; $n=9$ ) increased the size of axotomized RSNs compared with vehicle treatment.

To gain more insight into the cell size changes after axotomy with or without neurotrophin treatment, the cell profile size measurements were taken from the equivalent level of red nucleus from different groups (Table 1). This confirms that there were no differences in mean cell profile sizes of contralateral RSNs among these groups and that BDNF- and NT-4-treated axotomized RSNs were significantly larger than the axotomized RSNs of all other treatment groups ( $p<0.05$; Newman-Keuls test). The axotomized RSNs treated with BDNF and NT-4/5 displayed cell profiles sizes that were not different from their contralateral counterparts, whereas the axotomized RSNs of all other groups were significantly smaller $(p<0.01$; except for NT-3 treatment, $p<0.05)$. The cell profile sizes of the untreated intact RSNs were comparable to the study by Mori et al. (1997).

Interestingly the effect of the BDNF application lasted beyond the $7 \mathrm{~d}$ period of infusion. In BDNF-treated animals, the median size of axotomized RSNs was $79 \%$ and $83 \%$ of the contralateral, intact RSNs on days 21 and 28, respectively (7 and $14 \mathrm{~d}$ after cessation of the BDNF treatment). The corresponding values from vehicle controls were 60 and $56 \%$, indicating a continuing decline in cell size over time (data not shown). As mentioned above, these data are based on infusions through cannulae positioned within $0.5-1.0 \mathrm{~mm}$ from the lateral border of the red nucleus. BDNF infusion had no effect on neuronal soma size if the cannula was placed further away, reflecting the limited diffusibility of this factor (see above). 

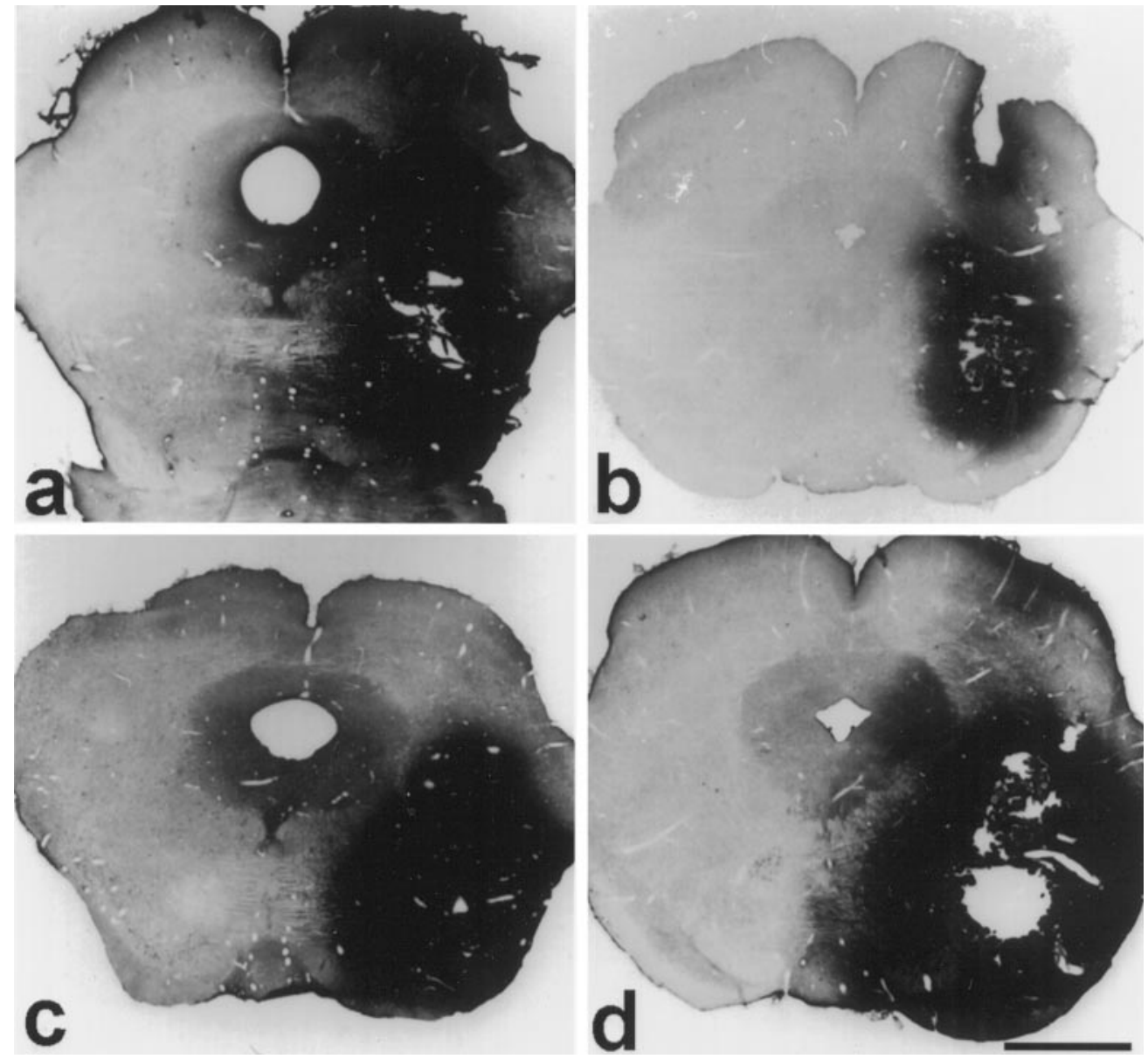

Figure 3. Immunohistochemistry for $\operatorname{NGF}(a), \operatorname{BDNF}(b), \mathrm{NT}-3(c)$, and NT-4/5 $(d)$ infused lateral to the red nucleus. NGF immunostaining $(a)$ reveals good tissue penetration of rhNGF covering almost an entire half of the midbrain in the coronal plane. In contrast, rhBDNF $(b)$ diff usion is limited around the center of the application needle within $\sim 1 \mathrm{~mm}$ of the cannula. Penetration of rhNT-3 (c) and rhNT$4 / 5(d)$ is comparable to that of rhNGF as shown by their respective immunostaining. $10 \times$ magnification. Scale bar, $1.5 \mathrm{~mm}$.

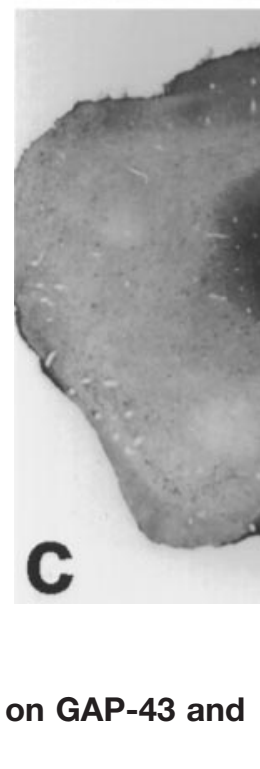
T $\alpha 1$-tubulin expression

Because infusion of BDNF and NT-4/5 into the vicinity of axotomized RSNs fully prevented their atrophy (Fig. 4, Table 1), we wished to determine whether infusion of neurotrophins might also prevent the decline in GAP-43 and T $\alpha 1$-tubulin mRNA expression typically observed during the second week after axotomy (Tetzlaff et al., 1991). The histogram of GAP-43 ISH quantification obtained from representative animals (marked by arrows in Fig. 6b) showed that on day 14 postaxotomy, only a subpopulation $(50 \%)$ of axotomized RSNs treated with vehicle displayed increases in GAP-43 hybridization, whereas the remainder showed signals near intact, control levels (Figs. 5a, 6a). In contrast, when treated with BDNF or NT-4/5 the majority $(>90 \%)$ of axotomized RSNs expressed increased levels of GAP-43 mRNA (Figs. 5b,c, 6a). Furthermore, vehicle-inf used and no-pump animals exhibited only a two- to threefold mean increase in GAP-43 mRNA expression, whereas treatment with BDNF or NT-4/5 typically produced mean increases of four- to sevenfold (Fig. 6b). In three cases, the increases were much higher (9- to 13-fold). GAP-43 expression in NGF- and NT3-treated animals was similar to that seen in controls. The differences among treatment groups were statistically significant $(p<0.01$; Kruskal-Wallis). Subsequent groupwise comparisons (Dunn's test) revealed that the median increase in GAP-43 ISH signal in the BDNF-treated $(5.3 \times, 25$ th-75th percentile: $5.1-6.5 \times ; n=6)$ and NT-4/5-treated $(7.6 \times, 25$ th-75th percentile: $5.1-9.8 \times ; n=4)$ groups were significantly different from that of the vehicle control group $(2.4 \times, 25$ th-75th percentile: $2.3-2.8 \times ; n=5)(p<0.05)$. In contrast, neither treatment with NGF $(3.0 \times, 25$ th -75 th percentile: $2.2-4.3 \times ; n=4)$ nor with NT-3 $(2.7 \times, 25$ th-75th percentile: $2.3-3.2 \times ; n=5$ ) produced increases in GAP-43 expression that were significantly different from that of the vehicle control.

Axotomized RSNs also exhibited higher T $\alpha 1$-tubulin expression in BDNF- and NT-4/5-treated animals compared with vehicle-treated controls (Fig. $5 d-f$ ). The histogram of representative animals (marked by arrows in Fig. $6 d$ ) illustrated that by $14 \mathrm{~d}$ after axotomy, $\sim 60 \%$ of the RSNs displayed T $\alpha 1$-tubulin ISH signals at levels below their contralateral counterparts, whereas $<20 \%$ showed increased level of expression (Fig. $6 c$ ). In marked contrast, T $\alpha 1$-tubulin expression was higher on the lesioned side in more than half of the RSNs treated with BDNF or NT-4/5 (Fig. 6c). Mean T $\alpha 1$-tubulin ISH signals, expressed as multiples of contralateral values, ranged from 0.4 to $1.1 \times$ in both "no-pump" and vehicle control groups (Fig. 6d). In BDNF- and NT-4/5-treated animals, values were between 1.3 and $2.3 \times$. Inf usion of NGF or NT-3 produced mean values that did not differ from that of controls (range, 0.4-1.4×). These differences among groups were statistically significant ( $p<0.01$; Kruskal-Wallis), and subsequent groupwise comparisons demonstrated that the median increases in T $\alpha 1$-ISH signal of the BDNF- $(1.6 \times, 25$ th75th percentile: $1.3-1.8 \times ; n=6)$ and the NT-4/5-treated $(1.6 \times$, 25th-75th percentile: $1.3-1.9 \times ; n=4)$ groups were significantly different $(p<0.05)$ from that of the vehicle-treated control group 


\section{Axotomized}
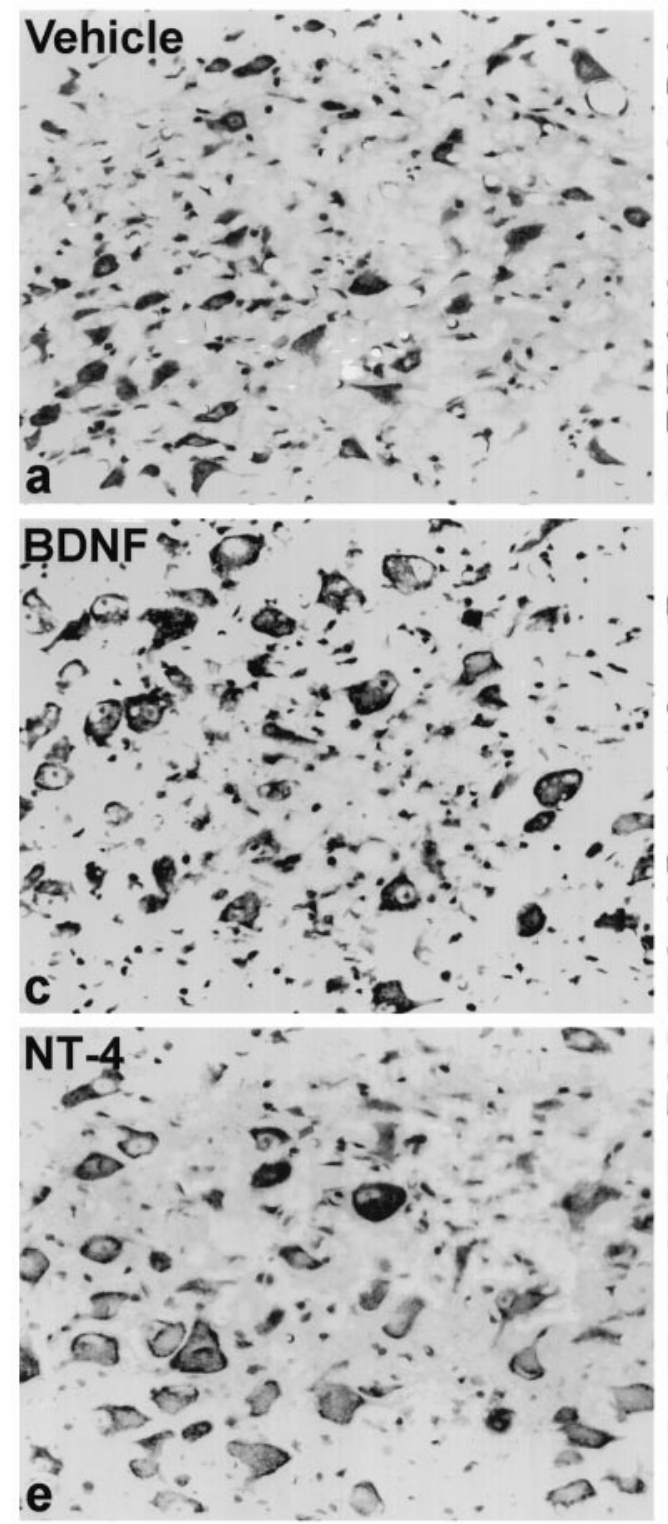

\section{Contralateral}
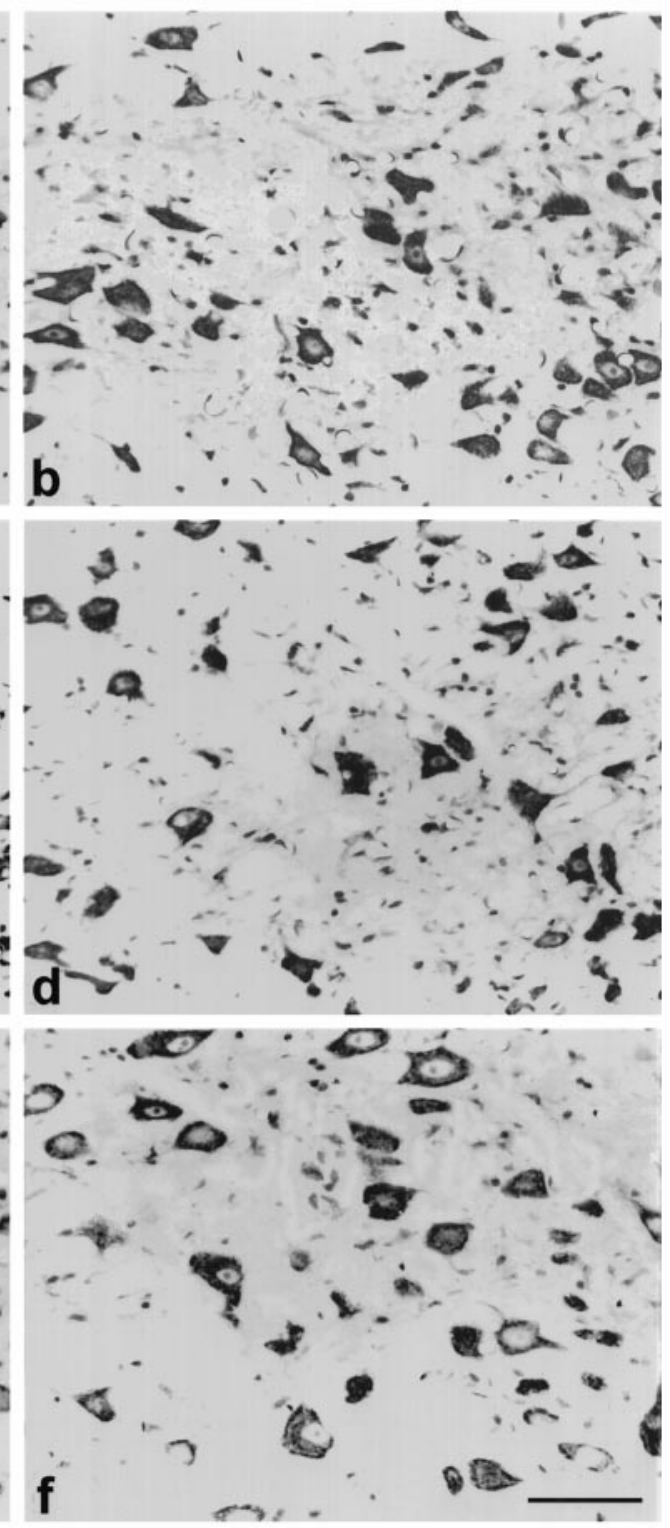

Figure 4. Cresyl violet staining of vehicle- or neurotrophin-treated RSNs $14 \mathrm{~d}$ after axotomy $(a, c, e)$ and their contralateral counterparts $(b, d, f)$. Note the severe atrophy of vehicle-treated RSNs ( $a$ vs $b$ ). This atrophy is fully prevented in axotomized RSNs treated with $\operatorname{BDNF}(c)$ or NT-4/5 (e), displaying the cell profile sizes comparable to the contralateral RSNs $(d, f)$. Note that the axotomized and neurotrophin-treated RSNs are chromatolytic. $400 \times$ magnification. Scale bar, $50 \mu \mathrm{m}$.
$(0.67 \times, 25$ th -75 th percentile: $0.57-0.76 \times ; n=6)$. Neither treatment with NGF $(0.75 \times, 25$ th -75 th percentile: $0.69-0.98 \times ; n=4)$ nor with NT-3 $(0.87 \times, 25$ th-75th percentile: $0.65-1.1 \times ; n=5)$ resulted in median T $\alpha 1$-tubulin ISH signals different from those of the vehicle-treated controls.

\section{Stimulation of rubrospinal regeneration into peripheral nerve transplants}

Predegenerated sciatic nerve segments of 30-40 mm length were inserted into $\mathrm{C} 4$ lesions of the rubrospinal tract, and regeneration was assessed by retrograde labeling with FG 2 months later. Typically these experiments resulted in a mean of $43 \pm 9.3$ regenerating neurons in control rats $(n=6)$ (Fig. $7 c$, open symbols). Animals receiving BDNF inf usions into the vicinity of the red nucleus, however, had a mean number of $131 \pm 19.7$
Table 1. Mean cell profile sizes $\left(\mu \mathrm{m}^{2}\right)$ of RSN $14 \mathrm{~d}$ after axotomy, with or without neurotrophin treatment

Mean cell size $\left(\mathrm{mm}^{2}\right)$

\begin{tabular}{lll}
\hline Group & Contralateral & Axotomized \\
\hline No pump $(n=6)$ & $444.6 \pm 36.5$ & $297.2 \pm 20.4$ \\
Vehicle $(n=5)$ & $449.6 \pm 29.1$ & $307.2 \pm 33.6$ \\
BDNF $(n=6)$ & $494.3 \pm 15.8$ & $545.6 \pm 59.7^{*}$ \\
NT-4/5 $(n=4)$ & $517.5 \pm 12.8$ & $603.1 \pm 35.2^{*}$ \\
NGF $(n=4)$ & $437.3 \pm 30.8$ & $338.1 \pm 17.3$ \\
NT-3 $(n=5)$ & $495.3 \pm 39.5$ & $368.2 \pm 41.3$
\end{tabular}

There is no significant difference in the contralateral profile sizes among different animal groups. The RSNs treated with BDNF or NT-4/5 are significantly larger than all the other groups $\left({ }^{*} p<0.05\right)$, whereas NGF- or NT-3-treated RSNs are not different from the control groups.

${ }^{*} p<0.05$; Newman-Keuls test. 


\section{GAP-43}

\section{To1-tubulin}
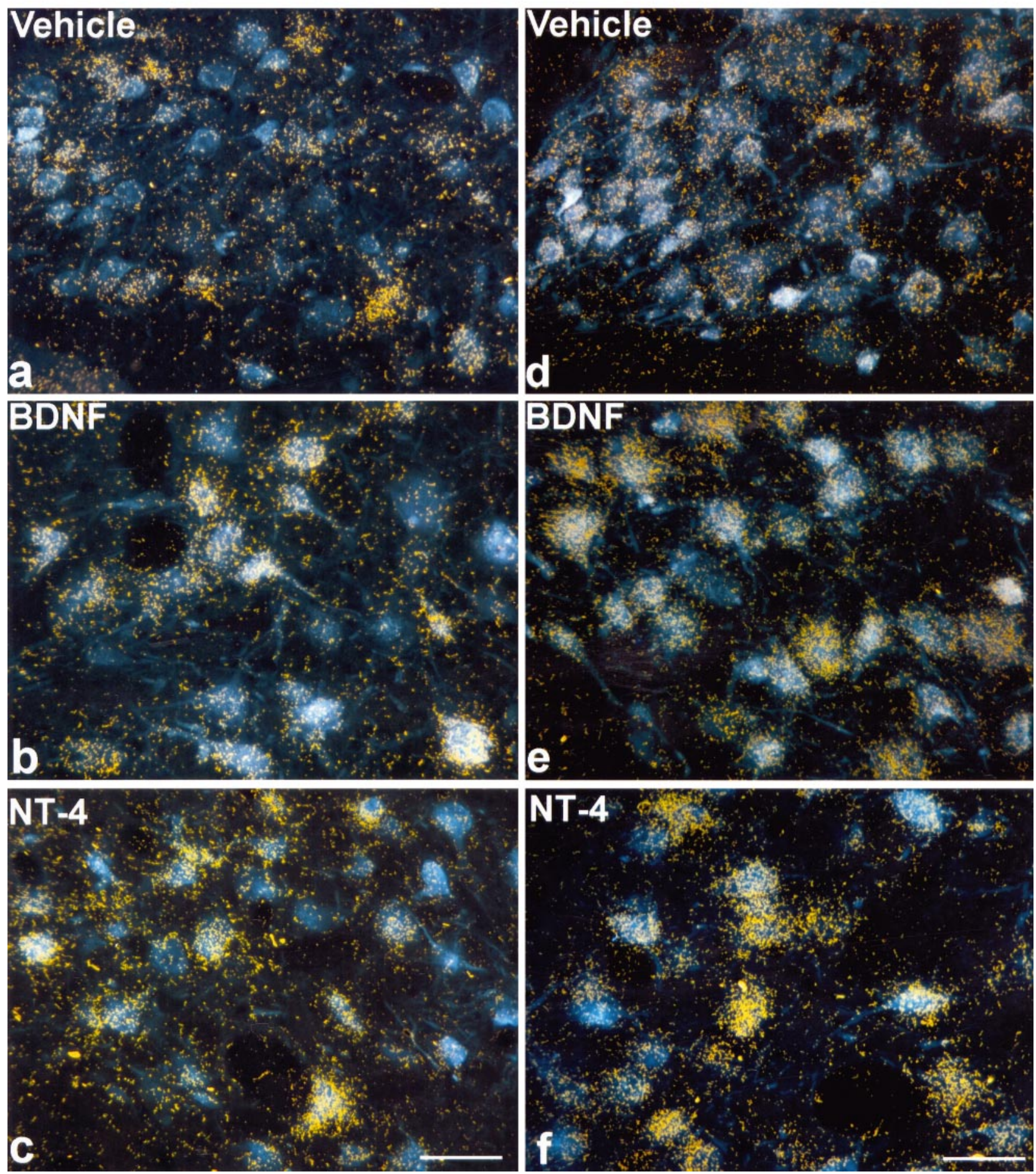

Figure 5. GAP-43 and T $\alpha 1$-tubulin ISH in axotomized RSNs treated with vehicle, BDNF, or NT-4/5. The FG-labeled, axotomized RSNs are visualized under fluorescent illumination, superimposed with autoradiographic silver grains representing the ISH signals in dark-field illumination. Note that only a subpopulation of axotomized RSNs display GAP-43 ISH signal with vehicle treatment $(a)$; in contrast, the majority of axotomized RSNs treated with BDNF $(b)$ or NT-4/5 (c) express high levels of GAP-43 mRNA. Moreover, an increase in T $\alpha 1$-tubulin expression is also observed in axotomized RSNs treated with BDNF $(e)$ or NT-4/5 $(f)$ compared with those RSNs treated with vehicle only $(d) .360 \times$ magnification. Scale bar, $40 \mu \mathrm{m}$.

regenerating RSNs $(n=6)$ (Fig. $7 c$, filled symbols), which was significantly different from the untreated controls $(p<0.01 ; t$ test). Representative sections through the red nucleus for both groups (marked by arrows in Fig. $7 c$ ) are shown in Figure $7 a, b$.

\section{DISCUSSION}

In the present study, we have shown that uninjured and axotomized RSNs express mRNA for the full-length trkB receptor. TrkA mRNA expression was not detected in the intact red nu- 


\section{GAP-43}

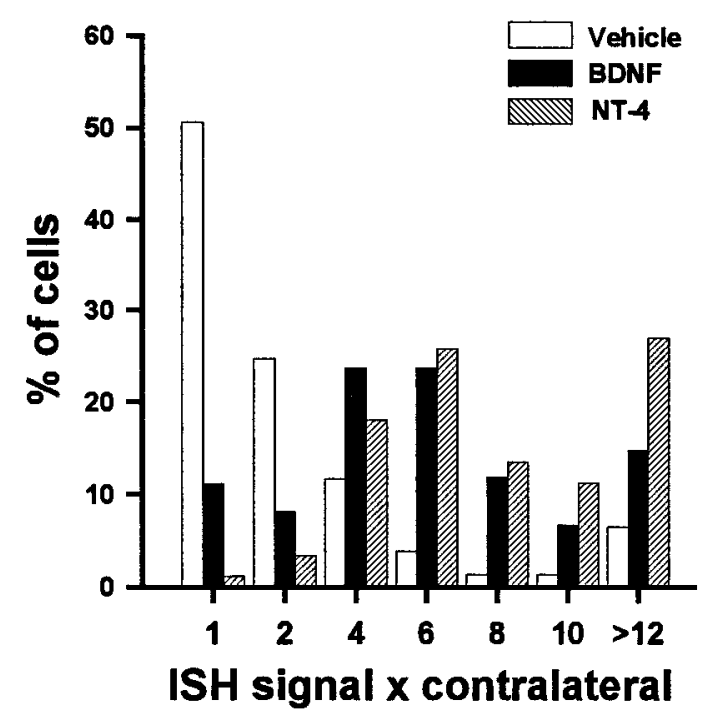

a

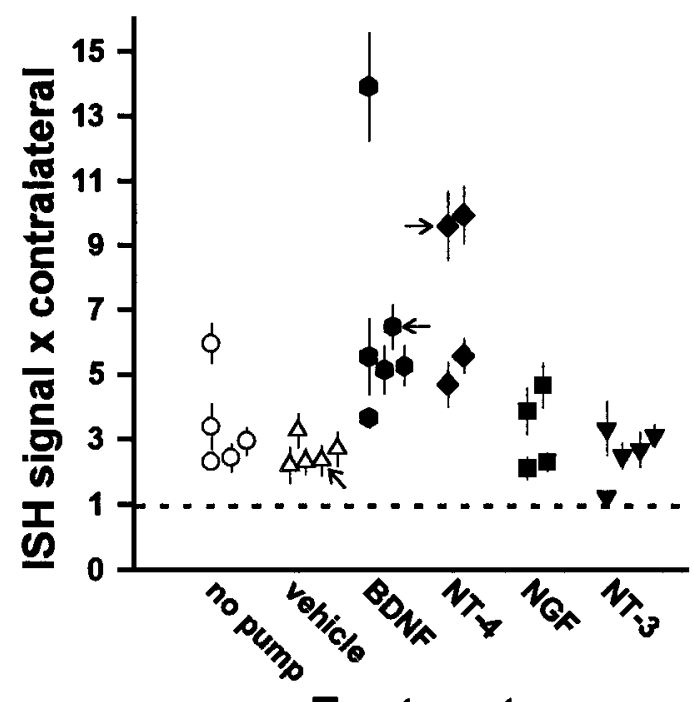

b

\section{Treatment}

\section{Ta1-tubulin}

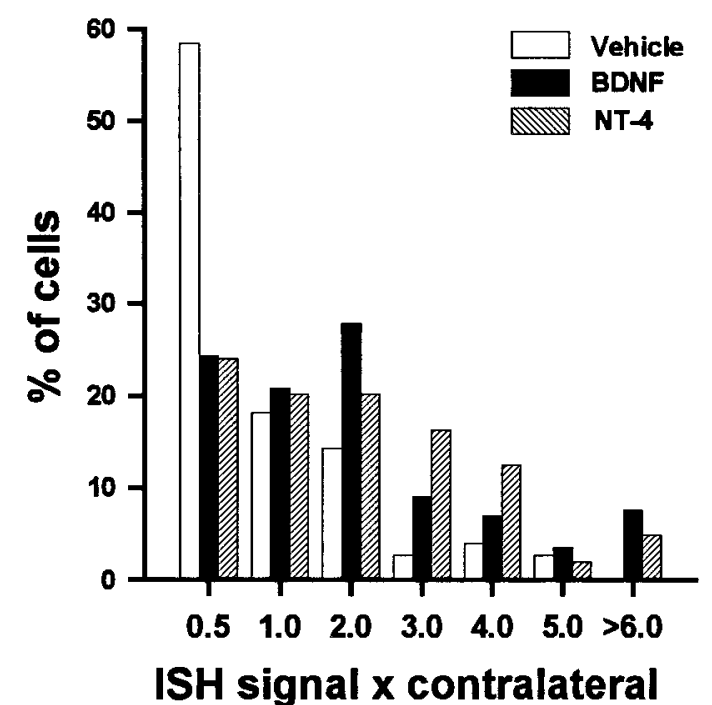

C

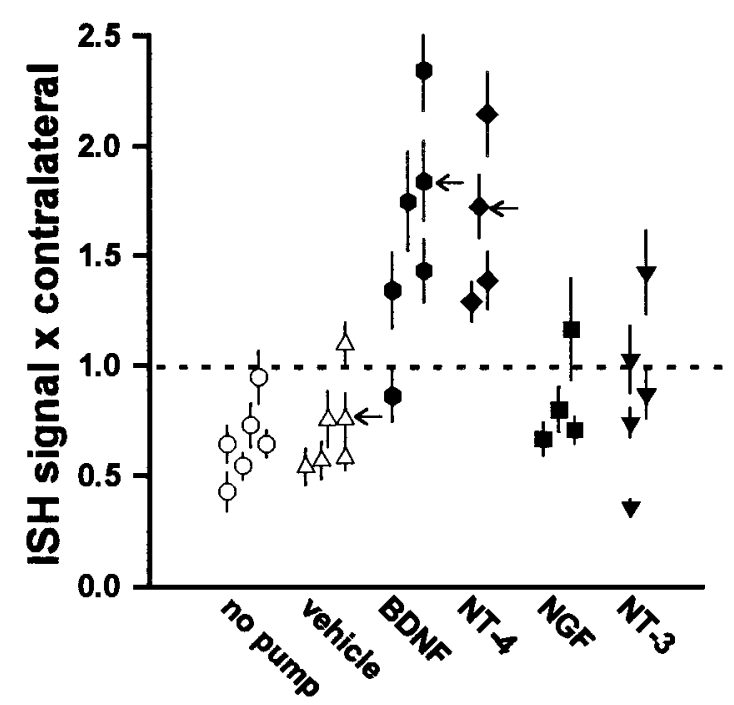

Treatment

Figure 6. Histograms of the percentage of cells displaying GAP-43 (a) or T $\alpha 1$-tubulin $(c)$ expression in multiples of their contralateral expression level, obtained from representative animals infused with vehicle, BDNF, or NT-4/5 (marked by arrows in $b$ and $d$ ). The labels of $x$-axis (multiples of contralateral) indicate an upper limit value of the bin category. Note the apparent shift to the right (increased expression) for both genes in the numbers of RSNs treated with BDNF or NT-4/5 compared with those treated with vehicle. Each symbol in $b$ and $d$ represents the mean $( \pm$ SEM) of ISH signals/cell normalized to that of contralateral RSNs, i.e., expressed as multiples of contralateral derived from an individual animal. Dashed lines indicate the expression level of contralateral $(=1)$. Note the increased expression of GAP-43 $(b)$ as well as T $\alpha 1$-tubulin $(d)$ in the animal groups treated with BDNF or NT-4/5 compared with the vehicle or no-pump control groups. 

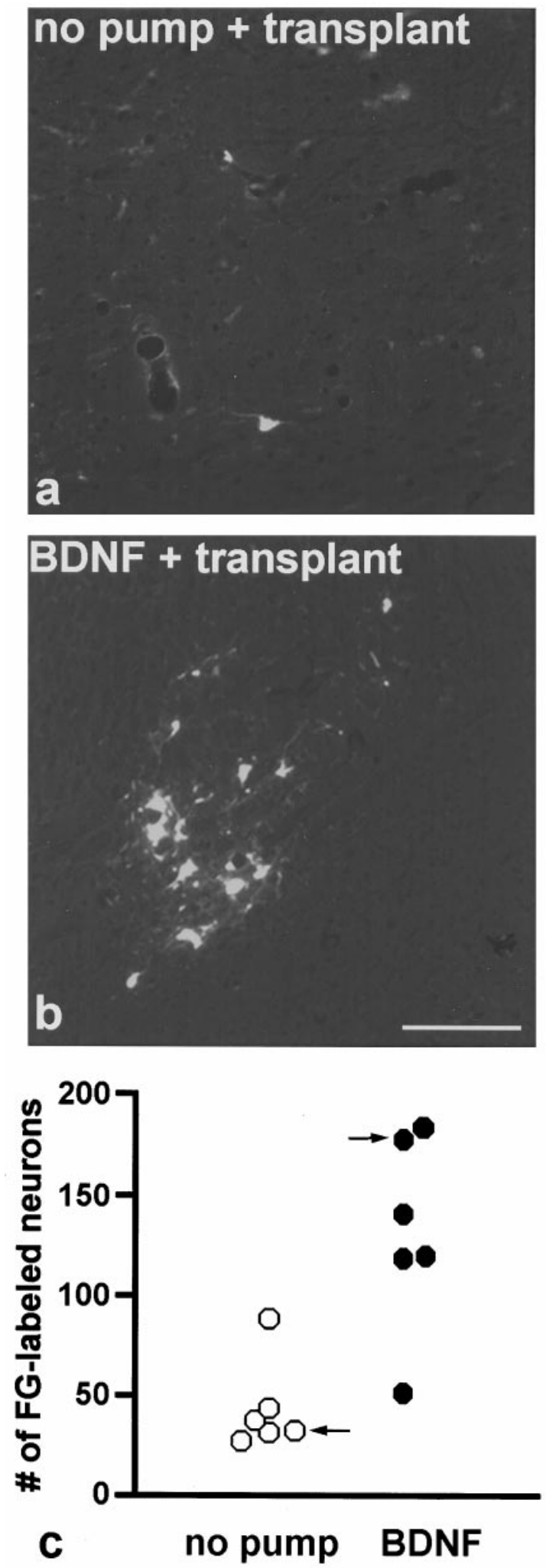

Figure 7. Photomicrographs of FG-labeled RSNs regenerated into a peripheral nerve transplant obtained from an animal without treatment $(a ; c$, marked by arrow) and of a BDNF-treated animal $(b ; c$, marked by arrow). $c$ shows the numbers of FG-labeled, i.e., regenerated, RSNs of individual animals without treatment (open symbols) and with BDNF treatment ( filled symbols). Note a severalfold increase in the number of FG-positive neurons in BDNF-treated animals compared with the animals without treatment $(p<0.01 ; t$ test). $160 \times$ magnification. Scale bar, $100 \mu \mathrm{m}$. cleus, although like p75 it was expressed in a few cells after axotomy at the cervical level of the spinal cord. Full-length trkC, including isoforms bearing amino acid inserts in the kinase domain, were expressed at only very low levels in intact or axotomized RSNs. In accordance with the observed pattern of receptor expression, inf usion of the TrkB ligands BDNF or NT-4/5 during the second week after spinal cord transection fully prevented the atrophy of axotomized RSNs, which remained chromatolytic. Moreover this infusion also maintained the axotomy-induced increase in GAP-43 and T $\alpha 1$-tubulin mRNA expression. In contrast, NGF and NT-3 treatment were without effect. In a subsequent experiment, BDNF treatment produced a severalfold increase in the number of axotomized RSNs regenerating into peripheral nerve grafts implanted into the cervical transection site. Taken together, these findings support the hypothesis that neuronal atrophy and the concomitant failure of injured cells to maintain expression of regeneration-associated genes are important factors that limit the regenerative capacity of axotomized CNS neurons. Furthermore, these effects of axotomy can be attenuated by application of appropriate trophic factors, thereby enhancing the capacity of the injured cell to sustain regrowth of its axon.

Interestingly, the prevention of reduction in cell size after axotomy by BDNF and NT-4/5 did not include a normalization of the neuronal morphology, which remained chromatolytic. Because the cell size could be maintained by the application of trophic factors, we feel justified to use the term atrophy, which implies the lack of some trophic support. It is difficult to evaluate the persisting chromatolytic response after neurotrophin application. Various degrees of chromatolysis are seen in both regenerating and nonregenerating neurons, as well as within the same neuronal phenotypes (for review, see Lieberman, 1971; Goldstein et al., 1987). Thus, the significance of a chromatolytic response for the regenerative success of a neuron is incompletely understood, and we therefore focused on the more prominent representatives of regeneration-associated genes.

\section{Receptor expression and effects of neurotrophins on atrophy}

The expression of neurotrophin receptors in uninjured RSNs is reminiscent of spinal cord and brainstem motoneurons, which also predominantly express full-length trkB receptors (Koliatsos et al., 1994; Piehl et al., 1994; Kobayashi et al., 1996). However, RSNs and lower motoneurons respond differently to injury. Axotomy produces an increase in trkB expression as well as de novo expression of the p75 neurotrophin receptor in motoneurons (Piehl et al., 1994; Kobayashi et al.,1996). In contrast, trkB expression decreased in axotomized RSNs, and p75 expression became detectable in only a small number of cells. The decline in trkB mRNA expression was prevented in axotomized RSNs by BDNF infusion (data not shown), suggesting that RSNs remain responsive to BDNF and NT-4/5, which was consistent with the observed prevention of their axotomy-induced atrophy.

The effect of NT-3 on the atrophy of axotomized RSNs did not reach statistical significance. This is reminiscent of the moderate effect of NT-3 in contrast to BDNF on survival of axotomized facial motoneurons of newborn rats (Sendtner et al., 1992; Koliatsos et al., 1993; Yan et al., 1993). Moreover, NT-3 application to axotomized motoneurons of adult rats has little effect on cell size (Fernandes et al., 1995; Tuszynski et al., 1996). We are confident that this marginal effect of NT-3 is not attributable to technical deficiencies, because immunostainings for NT-3 demonstrated 
good penetration of this factor through the relevant tissue. In addition, in parallel experiments infusions of NT-3 fully prevent the axotomy-induced cell death of adult corticospinal neurons (Giehl and Tetzlaff, 1996). In this context, it is important to note that trkC isoforms with insertions in the kinase domain are limited in their downstream signaling capacities (Tsoulfas et al., 1993, 1996; Guiton et al., 1995). In contrast to RSNs, corticospinal neurons express high levels of full length trkC, and the noninserted isoform is predominant (N. R. Kobayashi and W. Tetzlaff, unpublished observation). Therefore, the marginal effect of NT-3 on axotomized RSNs may be attributable not only to the lower level of expression of full length trkC but also to coexpression at comparable levels of isoforms carrying amino acid insertions in their kinase domains. Although in the present study, axotomized RSNs in the adult rat did not appear to be responsive to NT-3, axotomized RSNs are rescued from cell death by application of exogenous NT-3 in newborn rats (Diener and Bregman, 1994). Presently, it is unknown whether this difference might be attributable to developmental differences in the pattern of trkC expression in RSNs. It should also be noted that axotomized corticospinal neurons rescued by application of NT-3 remain atrophic, in contrast to those rescued by treatment with BDNF (Giehl and Tetzlaff, 1996). Therefore, it is possible that NT-3 may be a survival factor for RSNs, even in adulthood, but may not influence cell size. This also implies that different signaling pathways are activated by stimulation of the TrkB and TrkC receptors, even when they are expressed contemporaneously in the same cell.

\section{Effect of the neurotrophins on regeneration-associated gene expression}

We show here that BDNF and NT-4/5 but not NGF, NT-3, or vehicle maintained the increased levels of GAP-43 and T $\alpha 1$ tubulin mRNA expression in axotomized RSNs. This differential responsiveness to the neurotrophins is consistent with the pattern of trk receptor expression. In essence, the expression of fulllength trkB receptors would provide means for a direct stimulation of RSNs by BDNF or NT-4/5. Likewise, BDNF has been reported to stimulate GAP-43 and T $\alpha 1$-tubulin expression in axotomized facial motoneurons that express trkB (Fernandes et al., 1995), and NGF regulates the expression of these same genes in neurons of the PNS that express trkA (Verge et al., 1990; Miller et al., 1994; Mohiuddin et al., 1995). Furthermore, BDNF stimulates the expression of GAP-43, but not T $\alpha 1$-tubulin, in axotomized retinal ganglion cells (Fournier et al., 1997). Thus, regulation of regeneration-associated genes by BDNF is contextdependent and distinct in different neuronal systems.

We do not know, however, how directly the expression of GAP-43 and T $\alpha 1$-tubulin is controlled by BDNF- or NT-4/5activated signaling pathways. We cannot rule out the possibility that the neurotrophins indirectly maintain the expression of these genes via a pleiotrophic effect. Interestingly, we found that BDNF had no effect on the baseline expression of GAP-43 in uninjured RSNs (N. R. Kobayashi and W. Tetzlaff, unpublished observation); thus, although GAP-43 mRNA expression can be maintained by $\mathrm{BDNF}$, its induction appears to require additional signals associated with axotomy. In contrast, BDNF infusion increased T $\alpha 1$-tubulin expression in intact RSNs (N. R. Kobayashi and W. Tetzlaff, unpublished observation) as well as in axotomized RSNs, indicating that GAP-43 and T $\alpha 1$-tubulin are not strictly co-regulated.

The differential regulation of GAP-43 and T $\alpha 1$-tubulin is further evidenced by the varying effects of NT-3 on these two genes in axotomized corticospinal neurons (Giehl et al., 1995), retinal ganglion cells (Kittlerova et al., 1996), and dorsal root ganglion cells (Mohiuddin et al., 1995; Gratto and Verge, 1996). Differential responses of these neuronal types to axotomy and distinct modes and doses of applied NT-3 may be partly responsible for these diverse outcomes. In addition, as discussed above, both the absolute and relative levels of trkC isoforms carrying insertions in the tyrosine kinase domain may differ in these models, contributing to the apparent discrepancies. Moreover, although NT-3 binds most avidly to trkC, it can also bind to trkA or trkB, so that different signaling cascades may be activated by NT-3 on cells expressing distinct complements of trk receptors (Davies et al., 1995; Ryden and Ibanez, 1996). Further complexity is added by emerging evidence that the different neurotrophins may elicit distinct downstream responses, even if their actions are mediated through the same cognate receptor (Belliveau et al., 1997). These data underline the necessity for analyzing the specific effects of the different neurotrophins in each neuronal system of interest, rather than relying on inference.

\section{Neurotrophins and CNS regeneration}

Several studies have demonstrated that local application of neurotrophins can enhance regenerative sprouting of various CNS axons (Schnell et al., 1994; Tuszynski et al., 1994; Xu et al., 1995; Oudega and Hagg, 1996; Ye and Houle, 1997). In these experimental paradigms, neurotrophins are applied to the vicinity of the axons and may exert local trophic and/or tropic effects. This stands in contrast to the model introduced here in which application of neurotrophins to the parent cell bodies enhances their regenerative propensity even after injury at greater distances. We hypothesize that this effect is mediated through the stimulation of regeneration-associated genes. T $\alpha 1$-tubulin and GAP-43 are highly expressed during axonal outgrowth in development and are re-expressed in regenerating PNS neurons (Skene and Willard, 1981; Miller et al., 1987, 1989; Skene, 1989; Tetzlaff et al., 1989). Increased tubulin expression after axotomy is believed to play a role in the replacement of the lost axoskeleton (for review, see Bisby and Tetzlaff, 1992). GAP-43 is concentrated at the axonal growth cone where it seems to play an important role in the transduction of growth cone guidance signals (for review, see Benowitz and Routtenberg, 1997). In vitro, GAP-43 conveys on neurons a greater propensity to grow (Aigner and Caroni, 1995). This is consistent with the close correlation between GAP-43 expression and successful regeneration of CNS neurons into peripheral nerve transplants (Doster et al., 1991; Campbell et al., 1992; Schaden et al., 1994; Tetzlaff et al., 1994; Vaudano et al., 1995). Ordinarily, only a very small fraction of axotomized RSNs typically regenerate into nerve grafts (Richardson et al., 1984; Houle, 1991). This appears to be attributable to the abortive expression of regeneration-associated genes and the concomitant atrophy of these cells. We show here that the stimulation of GAP-43 and T $\alpha 1$-tubulin expression by application of BDNF is correlated with an increased number of RSNs regenerating into peripheral nerve implants. It remains to be shown whether the stimulation of GAP-43 and T $\alpha 1$-tubulin expression alone is sufficient to induce this regenerative response, or whether other growth-associated proteins, e.g., CAP-23 (Widmer and Caroni, 1990) or microtubule-associated proteins (Fawcett et al., 1994; Nothias et al., 1995), might play a cooperative role in this process (Caroni et al., 1995). In any event, the present study supports the concept that the application of a specific neurotrophin to the vicinity of an axotomized CNS neuron can stimulate the expres- 
sion of regeneration-associated genes and enhance its propensity to regenerate.

\section{REFERENCES}

Aguayo AJ, Rasminsky M, Bray GM, Carbonetto S, McKerracher L, Villegas-Perez MP, Vidal-Sanz M, Carter DA (1991) Degenerative and regenerative responses of injured neurons in the central nervous system for adult mammals. Philos Trans $\mathrm{R}$ Soc Lond [Biol] 331:337-343.

Aigner L, Caroni P (1995) Absence of persistent spreading, branching and adhesion in GAP-43 induces nerve sprouting in the adult nervous system of transgenic mice. Cell 83:269-278.

Alderson RF, Wiegand SJ, Anderson KD, Cai N, Cho NJ, Lindsay RM, Altar CA (1996) Neurotrophin-4/5 maintains the cholinergic phenotype of axotomized septal neurons. Eur J Neurosci 8:282-290.

Altschul SF, Gish W, Miller W, Myers EW, Lipman DJ (1990) Basic local alignment search tool. J Mol Biol 215:403-410.

Anderson KD, Alderson RF, Altar CA, Distefano PS, Corcoran TL, Lindsay RM, Wiegand SJ (1995) Differential distribution of exogenous BDNF, NGF and NT-3 in the brain corresponds to the relative abundance and distribution of high-affinity and low-affinity neurotrophin receptors. J Comp Neurol 357:296-317.

Ausubel FM, Brent R, Kingston RE, Moore DD, Seidman JG, Smith KA, Struhl K (1987) Current protocols in molecular biology. New York: Wiley-Interscience.

Barbacid M (1995) Structural and functional properties of TRK family of neurotrophin receptors. Ann NY Acad Sci 766:442-458.

Barron KD, Banerjee M, Dentinger MP, Scheibly ME, Mankes R (1989) Cytological and cytochemical (RNA) studies on rubral neurons after unilateral rubrospinal tractotomy: the impact of GM1 ganglioside administration. J Neurosci Res 22:331-337.

Basi GS, Jacobson RD, Virag I, Schilling J, Skene JHP (1987) Primary structure and transcriptional regulation of GAP-43, a protein associated with nerve growth. Cell 236:597-600.

Belliveau DJ, Krivko I, Kohn J, Lachance C, Pozniak C, Rusakov D, Kaplan D, Miller FD (1997) NGF and neurotrophin-3 both activate trkA on sympathetic neurons but differentially regulate survival and neuritogenesis. J Cell Biol 136:375-388.

Benowitz LI, Routtenberg A (1997) GAP-43: an intrinsic determinant of neuronal development and plasticity. Trends Neurosci 20:84-91.

Bisby MA, Tetzlaff W (1992) Changes in cytoskeletal protein synthesis following axon injury and during axon regeneration. Mol Neurobiol 6:107-123.

Bonhoeffer T (1996) Neurotrophins and activity-dependent development of the neocortex. Curr Opin Neurobiol 6:119-126.

Bothwell M (1995) Functional interactions of neurotrophins and neurotrophin receptors. Annu Rev Neurosci 18:223-253.

Bovolenta P, Wandosell F, Nieto-Sampedro M (1993) Characterization of a neurite outgrowth inhibitor expressed after CNS injury. J Neurosci 5:454-465.

Campbell G, Lieberman AR, Anderson PN, Turmaine M (1992) Regeneration of adult rat CNS axons into peripheral nerve autografts: ultrastructural studies of the early stages of axonal sprouting and regenerative axonal growth. J Neurocytol 21:755-787.

Caroni P, Schwab ME (1988) Antibody against myelin-associated inhibitor of neurite growth neutralizes nonpermissive substrate properties of CNS white matter. Neuron 1:85-96.

Caroni P, Aigner L, Arber S, Botteri F, Kapfhammer J, Brenner H-R (1995) GAP-43 and CAP-23 induce nerve sprouting in the adult nervous system of transgenic mice. Soc Neurosci Abstr 21:14.

Chen DF, Jhaveri S, Schneider GE (1995) Intrinsic changes in developing retinal neurons result in regenerative failure of their axons. Proc Natl Acad Sci USA 92:7287-7291.

Davies AM (1994) The role of neurotrophins in the developing nervous system. J Neurobiol 25:1334-1348.

Davies AM, Minichiello L, Klein R (1995) Developmental changes in NT-3 signaling via TrkA and TrkB in embryonic neurons. EMBO J 14:4482-4489.

Diener PS, Bregman BS (1994) Neurotrophic factors prevent the death of CNS neurons after spinal cord lesions in newborn rats. NeuroReport 5:1913-1917.

Doster SK, Lozano AM, Aguayo AJ, Willard MB (1991) Expression of the growth associated protein GAP-43 in adult rat retinal ganglion cells following axon injury. Neuron 6:635-647.

Egan DA, Flumerfelt BA, Gwyn DG (1977) Perikaryal volume changes and the time course of chromatolysis following cervical and thoracic lesions. Acta Neuropathol 37:13-19.

Fawcett JW, Mathews G, Housden E, Goedert M, Matus A (1994) Regenerating sciatic nerve axons contain the adult rather than embryonic pattern of microtubule associated protein. Neuroscience 61:789-804.

Fernandes KL, Jasmin BJ, Tetzlaff W (1995) Effect of neurotrophins on mRNA levels in axotomized adult facial motoneurons. Soc Neurosci Abstr 21:1534.

Figueiredo BC, Skup M, Bedard AM, Tetzlaff W, Cuello AC (1995) Differential expression of p140trk, p75NGFR and GAP-43 genes in nucleus basalis magnocellularis, thalamus and adjacent cortex following neocortical infarctions and NGF treatment. Neuroscience 68: $29-45$.

Fournier AE, Beer J, Arregui CO, Essagian C, Aguayo AJ, McKerracher L (1997) Brain derived neurotrophic factor modulates GAP-43 but not T-alpha-1 expression in injured retinal ganglion cells of adult rat. J Neurosci Res 47:561-572.

Giehl KM, Tetzlaff W (1996) BDNF and NT-3, but not NGF, prevent axotomy-induced death of rat corticospinal neurons in vivo. Eur J Neurosci 8:1167-1175.

Giehl KM, Mestres P, Tetzlaff W (1995) BDNF and NT-3 exert differential and overlapping effects on GAP-43 and T $\alpha 1$-tubulin expression in axotomized corticospinal neurons of the rat. Soc Neurosci Abstr 21:1056.

Goldstein ME, Cooper HS, Bruce J, Carden MJ, Lee VM-Y, Schlaepfer WW (1987) Phosphorylation of neurofilament proteins and chromatolysis following transection of rat sciatic nerve. J Neurosci 7:1586-1594.

Gratto KA, Verge VMK (1996) The role of NT-3 in the regulation of GAP-43 and T $\alpha 1$-tubulin in intact and injured primary sensory neurons. Soc Neurosci Abstr 22:1001.

Guiton M, Gunnmoore FJ, Glass DJ, Geis DR, Yancopoulos GD, Tavare JM (1995) Naturally occurring tyrosine kinase inserts block high affinity binding of phospholipase c-gamma and SHC to TrkC and neurotrophin-3 signaling. J Biol Chem 270:20384-20390.

Houle J (1991) Demonstration of the potential for chronically injured neurons to regenerate axons into intraspinal peripheral nerve grafts. Exp Neurol 113:1-9.

Ip NY, Stitt TN, Tapley P, Klein R, Glass DJ, Fandl J, Greene LA, Barbacid M, Yancopoulos GD (1993) Similarities and differences in the way neurotrophins interact with the Trk receptors in neuronal and nonneuronal cells. Neuron 10:137-149.

Kaplan DR, Stephens RM (1994) Neurotrophin signal transduction by the trk receptor. J Neurobiol 25:1404-1417.

Kittlerova P, Bray GM, Aguayo AJ (1996) Differential effect of NT-3 on GAP-43 and tubulin $\alpha 1$ mRNA levels in axotomized retinal ganglion cells. Soc Neurosci Abstr 22:1000.

Klein R, Jing SQ, Nanduri V, O'Rourke E, Barbacid M (1991a) The trk proto-oncogene encodes a receptor for nerve growth factor. Cell 65:189-197.

Klein R, Nanduri V, Jing SA, Lamballe F, Tapley P, Bryant S, CordonCardo C, Jones KR, Reichardt LF, Barbacid M (1991b) The trkB tyrosine protein kinase is a receptor for brain-derived neurotrophic factor and neurotrophin-3. Cell 66:395-403.

Klein R, Lamballe F, Bryant S, Barbacid M (1992) The trkB tyrosine protein kinase is a receptor for neurotrophin-4. Neuron 8:947-956.

Kobayashi NR, Bedard AM, Hincke MT, Tetzlaff W (1996) Increased expression of BDNF and trkB mRNA in rat facial motoneurons after axotomy. Eur J Neurosci 8:1018-1029.

Koliatsos VE, Clatterbuck RE, Winslow JW, Cayouette MH, Price DL (1993) Evidence that brain-derived neurotrophic factor is a trophic factor for motor neurons in vivo. Neuron 10:359-367.

Koliatsos VE, Cayouette MH, Berkemeier LR, Clatterbuck RE, Price DL, Rosenthal A (1994) Neurotrophin 4/5 is a trophic factor for mammalian facial motor neurons. Proc Natl Acad Sci USA 91:3304-3308.

Korsching S (1993) The neurotrophic factor concept: a reexamination. J Neurosci 13:2739-2748.

Lamballe F, Klein R, Barbacid M (1991) TrkC, a new member of the trk family of tyrosine protein kinases, is a receptor for neurotrophin-3. Cell 66:967-979.

Lewin GR, Barde Y-A (1996) Physiology of the neurotrophins. Annu Rev Neurosci 19:289-317.

Lieberman AR (1971) The axon reaction: a review of the principal 
features of perikaryal responses to axon injury. Int Rev Neurobiol 14:49-124.

Lindholm D, Castren E, Berzaghi M, Bloechl A, Thoenen H (1994) Activity-dependent and hormonal regulation of neurotrophin mRNA levels in the brain-implications for neuronal plasticity. J Neurobiol 25:1362-1372.

Lindsay RM, Wiegand SJ, Altar CA, DiStefano PS (1994) Neurotrophic factors: from molecule to man. Trends Neurosci 17:182-190.

McKerracher L, David S, Jackson DL, Kottis V, Dunn RJ, Braun PE (1994) Identification of myelin-associated glycoprotein as a major myelin-derived inhibitor of neurite growth. Neuron 13:805-811.

Mearow KM, Kril Y, Diamond J (1993) Increased NGF mRNA expression in denervated rat skin. NeuroReport 4:351-354.

Middlemas DS, Lindberg RA, Hunter T (1991) TrkB, a neuronal receptor-tyrosine kinase: evidence for a full-length and two truncated receptors. Mol Cell Biol 11:143-153.

Miller FD, Naus CCG, Durand M, Bloom FE, Milner RJ (1987) Isotypes of $\alpha$-tubulin are differentially regulated during neuronal maturation. J Cell Biol 105:3065-3073.

Miller FD, Tetzlaff W, Bisby MA, Fawcett JW, Milner RJ (1989) Rapid induction of the major embryonic $\alpha$-tubulin mRNA T $\alpha 1$, during nerve regeneration in adult rat. J Neurosci 9:1452-1463.

Miller FD, Speelman A, Mathew TC, Fabian J, Chang E, Pozniak C, Toma JG (1994) Nerve growth factor derived from terminals selectively increases the ratio of p75 to trkA NGF receptors on mature sympathetic neurons. Dev Biol 161:206-217.

Mohiuddin L, Fernandez K, Tomlinson DR, Fernyhough P (1995) Nerve growth factor and neurotrophin-3 enhance neurite outgrowth and up-regulate the levels of messenger RNA for growth-associated protein GAP-43 and T $\alpha 1 \alpha$-tubulin in cultured adult rat sensory neurons. Neurosci Lett 185:20-23.

Mori F, Himes BT, Kowada M, Murray M, Tessler A (1997) Fetal spinal cord transplants rescue some axotomized rubrospinal neurons from retrograde cell death in adult rats. Exp Neurol 143:45-60.

Mukhopadhyay G, Doherty P, Walsh FS, Crocker PR, Filbin MY (1994) A novel role of myelin-associated glycoprotein, $\mathrm{MAG}$, as an inhibitor of axonal regeneration. Neuron 13:757-767.

Nothias F, Boyne L, Murray M, Tessler A, Fischer I (1995) The expression and distribution of tau proteins and messenger RNA in rat dorsal root ganglion neurons during development and regeneration. Neuroscience 66:707-719.

Offenhauser N, Bogm-Matthaei R, Tsoulfas P, Parada L, Meyer M (1995) Developmental regulation of full-length trkC in the rat sciatic nerve. Eur J Neurosci 7:917-925.

Oudega M, Hagg T (1996) Nerve growth factor promotes regeneration of sensory axons into adult rat spinal cord. Exp Neurol 140:218-229.

Piehl F, Frisen J, Risling M, Hokfelt T, Cullheim S (1994) Increased trkB mRNA expression by axotomized motoneurons. NeuroReport 5:697-700.

Ramon y Cajal S (1928/1991) Degeneration and regeneration of the nervous system. New York: Hafner.

Richardson PM, Issa VMK, Aguayo AJ (1984) Regeneration of long spinal axons in the rat. J Neurocytol 13:165-182.

Ryden M, Ibanez CF (1996) Binding of neurotrophin-3 to p75-LNGFR, trkA and trkB mediated by a single functional epitope distinct from that recognized by trkC. J Biol Chem 271:5623-5627.

Sambrook J, Fritsch EF, Maniatis T (1989) Molecular cloning: a laboratory manual, Ed 2. Cold Spring Harbor, NY: Cold Spring Harbor Laboratory.

Schachner M, Taylor J, Bartsch U, Pesheva P (1994) The perplexing multifunctionality of Janusin, a tenascin-related molecule. Perspect Dev Neurobiol 2:33-41.

Schaden H, Stuermer CA, Bahr M (1994) GAP-43 immunoreactivity and axon regeneration in retinal ganglion cells of the rat. J Neurobiol 25:1570-1578.

Schnell L, Schneider R, Kolbeck R, Barde Y-A, Schwab ME (1994) Neurotrophin-3 enhances sprouting of corticospinal tract during development and after adult spinal cord lesion. Nature 367:170-173.

Sendtner M, Holtmann B, Kolbeck R, Thoenen H, Barde Y-A (1992) Brain-derived neurotrophic factor prevents the death of motoneurons in newborn rats after nerve section. Nature 360:757-759.
Skene JHP (1989) Axonal growth-associated proteins. Annu Rev Neurosci 12:127-156.

Skene JHP, Willard M (1981) Axonally transported proteins associated with axon growth in rabbit central and peripheral nervous systems. J Cell Biol 89:96-103.

Soppet D, Escandon E, Maragos J, Middlemas DS, Reid SW, Blair J, Burton LE, Stanton BR, Kaplan DR, Hunter T, Nikolics K, Parada LF (1991) The neurotrophic factors brain-derived neurotrophic factor and neurotrophin-3 are ligands for the trkB tyrosine kinase receptor. Cell 65:895-903.

Squinto SP, Stitt P, Aldrich TH, Davis S, Bianco SM, Radziejewski C, Glass DJ, Msiakowski P, Furth ME, Valenzuela DM, DiStefano PS, Yancopoulos GD (1991) trkB encodes a functional receptor for brainderived neurotrophic factor and neurotrophin-3 but not nerve growth factor. Cell 65:885-893.

Tetzlaff W, Zwiers J, Lederis K, Cassar L, Bisby MA (1989) Axonal transport and localization of GAP-43-like immunoreactivity in regenerating sciatic and facial nerves of the rat. J Neurosci 9:1303-1313.

Tetzlaff W, Alexander SW, Miller FD, Bisby MA (1991) Response of facial and rubrospinal neurons to axotomy: changes in mRNA expression for cytoskeletal proteins and GAP-43. J Neurosci 11:2528-2544.

Tetzlaff W, Kobayashi NR, Giehl KMG, Tsui BJ, Cassar SL, Bedard AM (1994) Response of rubrospinal and corticospinal neurons to injury and neurotrophins. Prog Brain Res 103:271-286.

Tsoulfas P, Soppet D, Escandon E, Tessarollo L, Mendoza-Ramirez JL, Nikolics K, Parada LF (1993) The rat trkC locus encodes multiple neurogenic receptors that exhibit differential response to neurotrophin-3 in PC12 cells. Neuron 10:975-990.

Tsoulfas P, Stephens RM, Kaplan, DR, Parada LF (1996) TrkC isoforms with inserts in the kinase domain show impaired signaling responses. J Biol Chem 271:5691-5697.

Tuszynski MH, Peterson DA, Ray J, Baird A, Nakahara Y, Gage FH (1994) Fibroblasts genetically modified to produce nerve growth factor induce robust neuritic ingrowth after grafting to the spinal cord. Exp Neurol 126:1-14.

Tuszynski MH, Mafong E, Meyer S (1996) Central infusions of brainderived neurotrophic factor and neurotrophin-4/5, but not nerve growth factor and neurotrophin-3, prevent loss of the cholinergic phenotype in injured adult motoneurons. Neuroscience 71:761-771.

Valenzuela DM, Maisonpierre PC, Glass DJ, Rojas E, Nunez L, Kong Y, Stitt TN, Ip NY, Yancopoulos GD (1993) Alternative forms of rat TrkC with different functional capabilities. Neuron 10:963-974.

Vaudano E, Campbell G, Anderson PN, Davies AP, Woodhead C, Schreyer DJ, Lieberman AR (1995) The effects of a lesion or a peripheral nerve graft on GAP-43 upregulation in the adult rat brain: an in situ hybridization and immunocytochemical study. J Neurosci 15:3594-3611.

Verge VMK, Tetzlaff W, Bisby MA, Richardson PM (1990) Influence of nerve growth factor on neurofilament gene expression in mature primary sensory neurons. J Neurosci 10:2018-2025.

Verge VM, Merlio JP, Grondin J, Ernfors P, Persson H, Riopelle RJ, Hokfelt T, Richardson PM (1992) Colocalization of NGF binding sites, trk mRNA, and low-affinity NGF receptor mRNA in primary sensory neurons: responses to injury and infusion of NGF. J Neurosci 12:4011-4022.

Widmer F, Caroni P (1990) Identification, localization and primary structure of CAP-23, a particle-bound cytosolic protein of early development. J Cell Biol 111:3035-3047.

Xu XM, Guenard V, Kleitman N, Aebischer P, Bunge MB (1995) A combination of BDNF and NT-3 promotes supraspinal axonal regeneration into Schwann cell grafts in adult rat thoracic spinal cord. Exp Neurol 134:261-272.

Yan Q, Elliott JL, Matheson C, Sun J, Zhang L, Mu X, Rex KL, Snider WD (1993) Influences of neurotrophins on mammalian motoneurons in vivo. J Neurobiol 24:1555-1577.

Yan Q, Radeke MJ, Matheson CR, Talvenheimo J, Welcher AA, Feinstein SC (1997) Immunocytochemical localization of trkB in the central nervous system of the adult rat. J Comp Neurol 378:135-137.

Ye J-H, Houle JD (1997) Treatment of the chronically injured spinal cord with neurotrophic factors can promote axonal regeneration from supraspinal neurons. Exp Neurol 143:70-81. 